\title{
The Enlightenment of Internationalization of Higher Education on Foreign Language Education
}

\author{
Xin Ai \\ School of foreign language \\ Inner Mongolia Normal University \\ Hohhot Inner Mongolia China \\ aixinmail@yahoo.com
}

\begin{abstract}
To further improves the internationalization level of higher education has become a general consensus of universities at home and abroad. This paper starts from the characteristics and current situation of the internationalization of higher education, with the combination of the challenges faced by China's higher education, and adapts to the needs of globalization for foreign language education in higher education. On the basis of learning the experience of other countries, it explores how to update the concept of foreign language education in our country and promotes the innovation and development of foreign language education in the context of internationalization of higher education.
\end{abstract}

Keywords-foreign language education; higher education; internationalization

\section{INTRODUCTION}

As one of the core concepts of the development of modern higher education, the internationalization of higher education is one of the core concepts of modern higher education development proposed by UNESCO in the 1980s. Its internationalization level has increased year by year. In recent years, to speed up the process of internationalization of higher education has become a general consensus in universities at home and abroad. The internationalization of higher education is one of the effective ways to deal with the world culture shock. Therefore, how to update the concept of education and how to optimize the teaching content and means has a very important significance on the cultivation of international interdisciplinary talents. So the paper discusses the new trend of internationalization of higher education and the connotation of its dynamic development, and think deeply about how to improve the self-construction of Chinese college foreign language education by combining the policy adjustment and its implementation of higher foreign language education in the United States and Japan in recent years to promote the internationalization of higher education.

Since the 1980s, the research on the internationalization of higher education has shown a prosperous trend. The research on its connotation is mainly defined as the activities carried out at the institutional level. This concept is represented by Van de Water and others who define as the internationalization "a variety of activities, projects and services in international research, international educational exchanges and technical cooperation" (Arum, 1998) [1]. Jane Knight, a famous
Canadian scholar, argues that the internationalization of higher education is not a concrete event with a beginning and an end, nor is it an achievable goal. She defined the internationalization of higher education as "integrating internationalization and cross-cultural dimensions into the process of teaching, scientific research and service of institutions of higher learning (Knight, 2004: 6) [2]. Knight's general interpretation of the internationalization of higher education has generally been recognized by the education community. Later, she has expanded and perfected the internationalization of higher education in the context of the internationalization of higher education as integrating the internationalization, cross-cultural or global dimension into the process of the purpose, the functions and the implementation of higher education "(Knight, 2007: 214). [3 ]

At the different stages, the internationalization of higher education shows different values. Some scholars believe that we should be committed to improving the competitiveness of economic globalization, and some scholars stressed that the process of internationalization should be promoted from the political, economic, cultural and other aspects. With the deepening of the degree of globalization, the awareness of participation of the state, educational institutions and individual is also increasing, and the internationalization of higher education has attracted more and more attention from all sides.

\section{THE INTERNATIONALIZATION OF HIGHER EDUCATION AND FOREIGN LANGUAGE TEACHING}

The internationalization of higher education is not a concrete activity with beginning and end, nor is it an achievable purpose. The internationalization of higher education is defined as "integrating internationalization and cross-cultural dimensions into the process of teaching, scientific research and service of institutions of higher learning "(Knight, 2004: 6). "Internationalization is a dynamic, evolving and changing process which is changing the world of higher education and the globalization is changing the world of internationalization." [4]

Internationalization at home is a concept of transnational internationalization. The so-called domestic internationalization (internationalization at home) refers to the students do not have to leave away from country where they lived because of the purpose of learning, but also accept internationalization education at home. And in this process of 
education the vision of globalization is expanded, and international exchange capacity as well as the ability to understand multiculturalism is improve (Wachter, 2003: 5). [5]Whether it is internationalization at home or multinational internationalization, its ultimate goal is to cultivate students with international feelings and go abrading and participating in cross-internationalization is one of the means to achieve the ultimate goal. Relevant data shows that students who participate in cross-border international really account for only $10 \%$ of the total. How to get more students to participate in internationalization is an important issue that countries must solve today.

Countries in the world recognize the importance of the internationalization of higher education. They all reform the educational philosophy and adjust the foreign language education policy to meet the requirements of the development of globalization. For example, the Korean government in 1995 proposed a reform program, and Australia in 2005 vigorously promotes the "globalization curriculum". In 2002, the United Kingdom developed and implemented "Foreign language education development strategy". All these countries emphasize the importance of foreign language education, international education and cross-cultural exchange. In fact, governments have reached a certain consensus on the internationalization of higher education. The internationalization of higher education contributes to the improvement of foreign language ability and enhances the awareness of internationalization, thus breaking the language barrier, increasing communication and understanding among different regions, different countries, different races and cultures. But the internationalization of higher education can't deviate from the core objectives of education which requires us to explore the internationalization of higher education today deeply. Except that we need perceive from the traditional sense of the national level of behavior from the macro point of view, but also need to grasp the broad demand of the large number of students involved in international exchange and research on the value orientation of internationalization of higher education based on the individual level.

\section{THE CHALLENGES FACED BY CHINA}

The role of China in the globalized economy is increasingly prominent, and plays more and more important role, which shows the urgent need for interdisciplinary talents with crosscultural communication competence and internationalization, and puts forward severe challenges to our higher education.

Since the reform and open-up, Chinese economy has a rapid development in economy and the comprehensive national strengthen steadily, GDP ranks second in the world, and the international status has significantly improved, even in the period of financial crisis, the economy growth rate is still at the forefront of the world, the influence of world economy becomes more and more prominent. But the industry structure of our country is unreasonable, the scientific and technological innovation lags behind, the economic upgrade is urgent, these problems need to solve all the need of high quality and innovative talents. However, the higher education in China is relatively backward, and hasn't adapted to the international changes. In the international higher education market, China still is under input condition for education service. Although it brings about excellent education resources improve the education quality and cultivate more and more international vision versatile talent, however, the brain drain problem can't be ignored. And the education sovereignty inevitably suffers in some degree, we have to even face the grim situation that the loss of cultural identity. In the curriculum, our higher education can't adapt the global development of economy, and the opening of international curriculum also insufficient, the introduction of original English material is not widespread, Combined with the differences of education system, the degree awarded by Chinese high education universities does not highly recognized in the western countries. So the curriculum reform in China faces a great challenge to connect with the international market. Meanwhile, we should change the education concept from teaching methods, adjust the education target and talent cultivation target, and adopts the heuristic teaching.

\section{The EnLightenment OF Chinese Foreign LANGUAGE EDUCATION}

The great attention of the world on the internationalization of higher education, the advocacy of international vision and the policies, measures, regulations and programs to be carried out, have practical reference and significance for foreign language education in China. China should face up to the various crises and challenges, and vigorously promote the adjustment and reform of foreign language education to meet the new situation of internationalization of higher education.

First, the national foreign language education policy should be inclusive. The study of other languages and cultures in the world should be attached importance to, and foreign language education should be encouraged and supported through the "National Security Language" program. Because, GDP is not the only measure of "the rise of big countries," and the global economic integration put forward the requirements of internationalization on cross-cultural exchanges. At present, the majority of foreign language of Chinese institutions is nothing more than English, Japanese, Russian, German, etc., of which English has the largest proportion, followed by Japanese, and Arabic and small language learners are few, which simply can't meet the real needs of China and the relevant countries exchange. China should take the practice of the United States as reference, through the support of material and financial resources vigorously develop foreign language education and encourage nationals to study the language and culture of their country in order to improve the overall quality of the people and enhance the country's soft power in the global economy.

Second, the teaching content should be rich in international elements

Enrich the internationalization elements in foreign language teaching contents. To open international curriculum is an important part for higher education internationalization. According to the explanation of OECD, the so-called internationalization course is designed for students at home and abroad, and tends to internationalization. In the process of foreign language teaching in domestic colleges and universities, they often choose local foreign teaching material published by 
local editors. Increase the content of international courses, to change the priority of local foreign language textbooks published in the inherent model. The textbook compilation should reflect the world's latest information and views, and the content should pay more attention on Anglo-American and other Western developed countries and the country's political, cultural, economic, historical and values, to expand the students' vision, with the comprehensive understanding of the culture and philosophy of the advanced countries in the world, to cultivate international awareness.

These foreign language textbooks fully take into account the actual level of foreign language learners, and constantly introduce English textbooks in colleges and universities, so that foreign language teaching as a platform for students to acquire western humanistic ideas, not only helps students accumulate profound cultural heritage, but also will help improve the quality of foreign language teaching So today it is a problem that need to be think for foreign teaching how to increase the teaching content of western humanistic thought on the basis of existing teaching material.

Third, we must resolutely safeguard the education sovereignty, and promote local excellent culture. In the process of introducing international courses, we must put national interests in the first place, to strengthen the national identity, and education sovereignty is inviolable. In the teaching process, some courses can take a large number of foreign teaching cases as reference, but they must meet the actual situation in China and the specific circumstances. The practice of copying all without analysis should be abandoned.

Advocate the to preach of local culture and cultivate intercultural communicative competence. The internationalization of higher education aims to cultivate new learners with globalization and internationalization, in other words, to cultivate a world citizen with intercultural communicative competence. This requires learners to form a global mentality on the basis of local culture, to grasp the diversity and complexity of different cultures in the context of globalization, to raise the ability of understanding and analysis on the basis of different cultures. Students can deepen the identification of the outstanding national culture through foreign language learning, and finally form a sense of globalization based on the local and the world, which should be the core values and ultimate goal of college foreign language education.

For the talent flow, on the basis of encouraging students to study abroad, effective measures should be taken to attract foreign students from all over the world to study in China, to change the poor status of education receiving country in China.

\section{CONCLUSION}

To sum up, the internationalization of higher education in its development process has shown the characteristics of dynamic development and diversification, and countries in the world are trying to improve the level of internationalization to meet the needs of economic globalization of the new process. Due to facing to many challenges, China should make full use of the useful experience of other countries, combined with China's specific situation, and vigorously promote higher education reform to meet the international trend of higher education to develop the language education creatively.

\section{REFERENCES}

[1] Arum, S. 1998. "The Case for Diffusion in the Development of International Education". Journal of the Association of International Education Administrators 1. Pp. 12 - 16.

[2] Knight, J. In the course of teaching, research and service functions, 2004 "Bemodeled: Definition, Approaches, and Rationales" Journal of Studies in International Education1.

[3] Knight, J., "Internationalization: Concepts, Complexities and Challenges". In F. Forest \& P. G. Altbach. (Eds.). International Handbook of Higher Education. Dordrecht: Springer.

[4] Knight, J. 2004. "Bemodeled: Definition, Approaches, and Rationales" Journal of Studies in International Education1. pp. 5 - 31

[5] Wachter, B, 2003. "An Introduction at Home in Context". Journal of Studies in International Education 1. pp. 5 -11. 